\title{
Partisipasi Masyarakat Dalam Proses Pembentukan UU Di Era Reformasi
}

\section{Saifudin}

\section{Abstak}

The establishment of Acts is part of state Aouthority, it shall be transparent, and accountable. It also needs public participation. thus, it will produce a democratic Act and it will be benefical to the society. Furthemore, it is able to embody good govemance in accordance with the Constitution 1945.

\section{Pendahuluan}

Perubahan tatanan politik sebagai hasil dari gerakan reformasi 1998 , berpengaruh pula dalam proses pembentukan UU. Dalam pembentukan UU yang demokratis, partisipasi masyarakat di era reformasi terasa meningkat seiring dengan situasi politik yang semakin terbuka dalam mewujudkan demokratisasi di Indonesia. Tampaknya melalui gerakan reformasi 1998 telah membuka dan memperlancar terjadinya komunikasi politik antara rakyat dengan wakil-wakil rakyat di DP.R dalam menyampaikan aspirasinya. Komunikasi politik sebagai wujud adanya partisipasi masyarakat dalam proses pembentukan UU di era reformasi ini dapat dikemukakan beberapa contoh sumbangan pemikiran yang berasal dari: Komisi II RDPU dengan Dr. Indria Samego, Dr. Afan.Gaffar dan Prof. Dr. Nazaruddin. Samsuddin tanggal 9 Juni 1998 menyampaikan tèntang penyempurnaan UU Partai Politik dan Golongan Karya dan kualitas.demokrasi; ${ }^{1}$ Komisi Il RDPU dengan Prof. Dr. Harun Alrasid SH dan Prof. Dr. Ikhlasul Amal tanggal 10 Juni 1998 yang menyampaikan tentang urgensi UU Kepresidenan; ${ }^{2}$ Pimpinan 7 Fakultas Hukum Wilayah V DIY bertemu dengan FPP pada tanggal 2 September 1999 yang menyampaikan tentang aspirasi penolakan RUU KKN \& penolakan RUU Keselamatan dan Keamanan Bahaya: ${ }^{3}$ Persatuan Radio Siaran Swasta Nasional dan MPPI bertemu Fraksi Golkar tanggal 10 Pebruari 2000 untuk menyampaikan aspirasi PRSNI dan MPPI

'Sekretariat Jenderal DPR RI, Lampiran Laporan Sekretariat Jenderal DPR RI Persidangan IV Tahun 1997/1998, Jakarta, 1997/1998, hlm. 20.

2lbid., him. 22.

3Sekretariat Jenderal DPR RI, Lampiran Laporan Sekretariat Jenderal DPR RI Tahun Sidang 1999/ 2000, Jakarta, 1999/2000, him. 22. 
tentang. UU Penyiaran; ${ }^{4}$ Komisi VIII menemui IATMl, MKI dan Kelompok 20 Pengamat Migas tanggal 14 Juli 2000 yang menyampaikan pemaparan tentang RUU Migas dan Ketenagalistrikan. ${ }^{5}$ Dari beberapa contoh tentang partisipasi masyarakat dalam pembentukan UU di era reformasi ini tampak bahwa para pelaku yang memberikan sumbangan pemikiran berasal dari berbagai kalangan seperti akademisi, kelompok profesional, lembaga swadaya masyarakat (LSM) dll.

Melihat pada data awal tersebut, secara sederhana dapat dikemukakan bahwa masyarakat berkeinginan agar pembentukan UU tidak hanya memuaskan pihak legislator saja, ${ }^{6}$ tetapi juga dapat diterima oleh masyarakat luas. Karena, syarat keberlakuan undang-undang yang baik memerlukan tiga pijakan sekaligus yaitu filosofis, sosiologis dan yuridis. ${ }^{7}$ Partisipasi masyarakat dalam proses pembangunan - termasuk di bidang pembentukan undangundang ini- telah menjadi isu penting dalam konteks global dewasa ini. ${ }^{8}$

Bertalian dengan pembentukan UU yang partisipatif ini, di dalamnya mengandung dua makna yaitu proses dan substansi. Proses adalah mekanisme dalam pembentukan UU yang harus dilakukan secara transparan sehingga masyarakat dapat berpartisipasi memberikan masukan-masukan dalam mengatur suatu persoalan. Substansi adalah materi yang akan diatur harus ditujukan bagi kepentingan masyarakat luas sehingga menghasilkan suatu UU yang demokratis berkarakter responsif/populistis. ${ }^{9}$ Dengan demikian, antara partisipasi, transparansi dan demokratisasi dalam pembentukan undangundang merupakan satu kesatuan yang utuh dan tidak dapat dipisahkan dalam suatu negara demokrasi. ${ }^{10}$

${ }^{4}$ fbid., him. 319.

stbid., hlm. 474.

'Terence Ingman, The English Legal Process, Blackstone Press Limited, London, 1983, hlm. 181

${ }^{7}$ Radbruch, sebagaimana dikutip Satjipto Rahardjo menyatakan bahwa hukum itu harus memenuhi nilajnilai dasar keadilan, kegunaan dan kepastian hukum. Bertolak dari tiga nilai-nilai dasar tersebut maka Satjipto Rahardjo menyatakan hukum mempunyai tiga keabsahan beriakunya yaitu filsafati, sosiologis dan yuridis. Lihat Satipto Rahardjo, IImu Hukum, Cetakan Pertama, Alumni, Bandung, 1986, hlm. 20-21. Sementaraitu, Joeniarto dengan menggunakan istilah "sumber hukum" menyatakan bahwa sumber hukum itu sering dihubungkan dengan filsafat, sejarah dan masyarakat, sehingga bagi Joeniarto terdapat sumber hukum filosofis, sumber hukum historis dan sumber hukum sosiologis. Lihat Joeniarto, Selayang Pandang Sumber-sumber Hukum Tata Negara di Indonesia, (Liberty, Cetakan Keempat, Yogyakarta, 1983), hlm. 13.

${ }^{8}$ Gary Craig and Marjorie Mayo (Editor), Community Empowerment A Reader in Participation and Development, (Zed Books Ltd., London \& New Jersy, 1995), him. 1.

${ }^{9}$ Peristilahan mengenai hukum yang responsif/populistis ini dikemukakan oleh Moh. Mahfud MD untuk melihat perbedaan secara mendasar dengan peristilahan hukum yang konservatif/ortodoxs/elitis dalam disertasinya tahun 1993. Lihat Moh. Mahfud MD, Perkembangan Politik Hukum : Studi tentang Penganuh Konfigurasi Politik Terhadap Produk Hukum di Indonesia, disertasi, UGM, 1993, hIm. 66.

${ }^{10}$ Dilihat dari sudut pandang sosiologi hukum, proses pembentukan UU yang telah dilakukan secara partisipatif, transparan dan demokratis, maka pada gilirannya diharapkan UU yang dihasilkannya akan diterima oleh masyarakat dengan penuh kesadaran. Akan tetapi dari sudut pandang politik ternyata adanya partisipasi, 
Mengacu pada kenyataan tersebut, maka persoalan yang akan muncul adalah bagaimana mewujudkan proses pembentukan undang-undang yang partisipatif, transparan dan demokratis ? Sebab, permasalahan ini akan bersinggungan dengan kewenangan konstitusional yang diberikan kepada Presiden dan DPR sebagai lembaga legislatif dalam UUD 1945. Meskipun setelah adanya perubahan UUD 1945 tekanannya lebih diletakkan pada DPR. Presiden bertindak sebagai organ yang akan melaksanakan UU, sedangkan DPR yang keanggotaannya diisi melalui pemilihan umum bertindak dalam kapasitas sebagai wakil rakyat yang akan menyuarakan aspirasi rakyat. Akan tetapi, kadang-kadang DPR belum secara sungguhsungguh menyuarakan aspirasi rakyat yang diwakilinya, namun lebih tertarik untuk memperjuangkan kepentingan induk organisasi partainya. Di sinilah masyarakat yang kepentingannya dirugikan akan berpartisipasi memberikan masukan-masukan dalam proses pembentukan UU. Dengan demikian, tarikmenarik kepentingan akan terjadi di antara tiga kekuatan politik dalam pembentukan UU yaitu presiden, DPR. dan masyarakat.
Adanya partisipasi masyarakat ini tidak dapat diabaikan begitu saja oleh lembaga legislatif. Terlebih lagi dengan dibentuknya Mahkamah Konstitusi" yang salah satu kewenangannya adalah melakukan pengujian terhadap UU, maka partisipasi masyarakat akan menjadi lebih bermakna. Masyarakat yang kepentingannya diabaikan dan dirugikan oleh adanya UU dapat mengajukan tuntutan pengujian terhadap suatu UU.

Sejumlah problematik tarik-menarik kepentingan di atas, tampaknya tidak mudah untuk dicarikan jawabannya. Ketika pembentuk undang-undang kurang transparan, partisipatif dan demokratis sebagaimana banyak diperankan oleh orde baru- pada akhirnya masyarakat menggugatnya melalui gerakan reformasi. Akan tetapi, ketika proses pembentukan undang-undang akan dilakukan dengan pintu -transparansi, partisipatif dan demokratisasi yang dibuka. secara luas, maka akan menggeser kewenangan konstitusional yang telah diberikan oleh UUD 1945. Artinya, presiden dan DPR sebagai pemegang kekuasaan legislatif akan tertandingi dalam proses pembentukan undangundang. Sudah barang tentu transparansi,

transparansidan demokratisasi dalam proses pembentukan UU bukan merupakan suatujaminan diterimanya suatu produk UU oleh masyarakat, sebab, pertama meskipun terdapat partisipasi masyarakat tetapi pada akhimya keputusan tetap di tangan lembaga legislatif sehingga partisipasi tetap tidak berart; kedua, dalam suatu keputusan politik -termasuk UU - selalu saja ada kelompok yang tidak setuju dengan keputusan yang dibuat.

"Munculnya lembaga baru di bidang kekuasaan kehakiman yang diberi nama "Mahkamah Konstitusi" ini (Pasal 24 ayat (2) UUD 1945) dilakukan dalam Perubahan Ketiga UUD 1945, dengan kewenangan mengadili pada tingkat pertama dan terakhir yang putusannya bersifat final untuk: pertama, menguji UU terhadap UUD; kedua, memutus sengketa kewenangan lembaga Negara yang kewenangannya diberikan oleh UUD; ketiga, memutus pembubaran partai politik; dan keempatmemutus perselisihan tentang hasil pemillihan umum ( $\mathrm{Pasal} 24$ C ayat(1) UUD 1945). Selain itu, Mahkamah Konstitusi wajib memberikan putusan atas pendapat DPR mengenai dugaan pelanggaran oleh Presiden dan/atau Wakil Presiden menurut UUD (Pasal $24 \mathrm{C}$ ayat (2) UUD 1945). Lihat Jimly Asshiddiqie, Konsolidasi Naskah UUD 1945 Setelah Perubahan Keempat, Yarsif Watampone, (Cetakan Kedua, Jakarta, 2003), hlm. 54-57. 
partisipatif dan demokratisasi yang terlalu lúas inipun tidak akan memberikan hasil yang positif bagi penataan kekuasaan legislatif yang secara formal diatur dalam UUD 1945. Perlu dicarikan jalan pemecahan yang sebaikbaiknya yang dapat menjamin dan melindungi lembaga legisiatif dari tuntutan transparansi, partisipatif dan demokratisasi daiam proses pembentukan undang-undang. ${ }^{12}$ Tanpa adanya penataan yang seimbang antara kekuasaan legislatif dengan tuntutan tranparansi, partisipatif dan demokratisasi, UU yang dihasilkan akan tetap kurang responsif. Hasil yang dicapai tidak akan dapat secara optimal menampung berbagai kepentingan yang secara riil ada dalam tatanan kehidupan bermasyarakat, berbangsa dan bernegara.
Mengacu pada pemaparan latar belakang masalah di atas, dapat dikemukakan satu rumusan masalah pokok yaitu : bagaimana proses partisipasi masyarakat dalam pembentukan undang-undang di era reformasi ? Tulisan ini akan membatasi diri pada proses partisipasi masyarakat dalam pembentukan 3 (tiga) undang-undang, yakni UU Sisdiknas, UU Pemilu dan UU Ketenagakerjaan.

\section{Bingkai Teoritis}

Dalam UUD $1945^{13}$ telah dimuat sendisendi dasar pembentukan peraturan perundang-undangan -termasuk di dalamnya UU- yaitu sendi kerakyatan (demokrasi), ${ }^{14}$

12Persoalan ide keseimbangan antara pemegang kekuasaan legislatif dengan kepentingan masyarakat melalui partisipasi dalam pembentukan undang-undang ini, ditinjau dari pendekatan politik merupakan sesuatu yang tidak mungkin sebab hanya lembaga legislatiflah yang secara resmi memegang kekuasaan membentuk undang-undang. Akan tetapi ditinjau dari pendekatan sosiologi hukum keseimbangan antara kepentingan kekuasaan legislatif dengan masyarakat sangat pertu dilakukan, sebab sumber utama suatu hukum pada dasamya terdapat di masyarakat, sedangkan lembaga legislatif merupakan sumber hukum kedua setelah masyarakat. Artinya, hukum yang akan diberlakukan dalam suatu masyarakat sebaiknya menupakan kristalisasi dari nilai-nilai yang tumbuh dan berkembang di masyarakat. Jadi, lembaga legislatif dari sudut pandang sosiologi hukum hanya merupakan salah satu lembaga pembentuk hukum yang dalam hal ini dinamakan undang-undang.

${ }^{13}$ Cita-cita pembentukan hukum nasional yang akan berfungsi untuk menyebarkan dan memelihara nilainilai yang oleh masyarakat dirasa benar telah lahir tumbuh dan berkembang semenjak berdirinya Negara Republik Indonesia pada 17 Agustus 1945. Dengan kemerdekaan, bangsa Indonesia akan melakukan perubahan sosial melalui tatanan hukum nasional yang sejalan dengan jiwa, semangat dan alam kemerdekaan Sebagai konsekuensi logis dari Proklamasi, pada saat itu mulai berdiri tata hukum baru, yaitu Tata Hukum Indonesia dengan Proklamasi tersebut sebagai "tindakan pertama" atau "ketentuan pertama" atau "norma pertama" atau dapat juga disebut sebagai "ketentuan pangkal"nya. Lihat Joeniarto, Selayang... Op. Cit., hlm. 19.

${ }^{14}$ Gagasan demokrasi yang diperjuangkan sejak masa perjuangan sebelum Indonesia merdeka adalah yang sesuai dengan Indonesia sendiin, yang tentu saja berbeda dengan Barat yang berlatar filsafat individualisme, liberalisme dan kapitalisme. Tetapi dengan mengkritik individualisme, tidak serta merta menjadikan mereka terposisikan dalam Marxisme yang merupakan anti tesis atas individualisme-liberalisme dan kapitalisme. Tokohtokoh bangsa ketika itu menghendaki sifat kerakyatan yang asli, dan yang diidialkan adalah justru paham kolektivisme. Lihat Jimly Asshiddiqie : Gagasan Kedaulatan Rakyat Dalam Konstitusi dan Pelaksanaannya di Indonesia, (Ikhtiar Baru Van Hoeve, Cetakan Pertama, Jakarta, 1994), him. 30-31. 
negara berdasar atas hukum, ${ }^{15}$ dan negara berdasar atas konstitusi (konstitusionalisme). ${ }^{16}$ Dengan demikian, peraturan perundangundangan yang akan digunakan untuk mengatur kehidupan bersama dalam wadah Negara Kesatuan Republik Indonesia haruș dituangkan dalam sistem konstitusional yang berada di dalam konsepsi negara hukum yang demokratis atau negara demokrasi yang berdasarkan atas hukum. ${ }^{17}$

Pemahaman tentang demokrasi sudah barang tentu mempunyai konsekuensikonsekuensi yang harus diperhatikan. Dalam kaitan ini, Afan Gaffar memberikan lima hal yang merupakan elemen empirik sebagai konsekuensi dari demokrasi, yaitu :

i. Masyarakat menikmati apa yang menjadi hak-hak dasar mereka termasuk hak untuk berserikat, berkumpul (freedom of assembly), hak untuk berpendapat (freedom of speech), dan menikmati pers yang bebas (freedom of the press);

ii. Adanya pemilihan umum yang dilakukan secara teratur di mana si pemilih bebas menentukan pilihannya tanpa ada unsur paksaan;

iii. Sebagai konsekuensi kedua hal di atas, warga masyarakat dapat mengaktualisasikan dirinya secara maksimal di dalam kehidupan politik dengan melakukan partisipasi politik yang mandiri (autonomous participation) tanpa digerakkan;

iv. Adanya kemungkinan rotasi berkuasa sebagai produk dari pemilihan umum yang bebas;

v. Adanya rekruitmen politik yang bersifat terbuka (open recruitment) untuk mengisi posisi-posisi politik yang penting di dalam proses penyelenggaraan negara. ${ }^{18}$

Konsekuensi-konsekuensi ini akan memberikan kesempatan kepada rakyat selaku warga negara untuk melakukan hak dan kewajijban politiknya dalam bernegara dalam, sistem politik yang demokratis.

Meskipun telah ada berbagai teori dalam melihat hubungan antara si wakil dengan yang diwakili tersebut, demokrasi perwakilan tetap bermasalah. Dalam demokrasi perwakilan akan memandang dan mengasumsikan rakyat sebagai orang yang tidak pertu dilibatkan dalam proses pengambilan keputusan publik. Rakyat lebih baik apatis dan bijaksana untuk tidak menciptakan tindakan-tindakan yang merusak

${ }^{15} \mathrm{Negara}$ hukum atau yang lebih tepat adalah negara yang berdasar atas hukum ini merupakan genus begrip, sedangkan sebagai species begrip konsep negara hukum ini mempunyai lima macam yaitu: nomokrasi Islam, the nule of law, rechtsstaat, socialist legality dan negara hukum Pancasila. Lihat M TahirAzhary: Negara Hukum : Suatu Studi tentang Prinsip-prinsipnya Dilihat dari Segi Hukum Islam, Implementasinya pada Periode Negara Madinah dan Masa Kini, (Bulan Bintang, Cetakan. Pertama, Jakarta, 1992), hlm. 63.

${ }^{16}$ Bagir Manan, Dasar-dasar Konstitusional Peraturan Perundang-undangan Nasional, disajikan dalam pendidikan singkat "Kajian Perundang-undangan" untuk para pengajar Fakultas Hukum se Sumatera, yang diselenggarakan oleh Fakultas Hukum Universitas Andalas, tanggal 11 - 18 Oktober 1993, hlm. 9-11.

${ }^{17}$ Dinamika pemikiran mengenai konsep pemikiran negara yang berdasar atas hukum dan negara kerakyatan (demokrasi) ini sudah berlangsung sejak darijaman Yunani dan Romawi Kuno. Lihat Jimly Asshiddiqie , op. cit, him. 11.

${ }^{18}$ Afan Gaffar, Pembangunan Hukum dan Demokrasi, dalam Politik Pembangunan Hukum Nasional, Penyunting Muh. Busyro Muqoddas dkk., (Ull Press, Yogyakarta, 1992), him, 106. 
budaya, masyarakat dan kebebasan. ${ }^{19} \mathrm{Dj}$ bawah sebuah pemerintahan perwakilan yang elitis ini, ${ }^{20}$ warga negara sering menyerahkan kekuasaan yang sangat besar yang dapat digunakan sesukanya atas keputusankeputusan yang luar biasa penting. Inilah sisi gelap dari demokrasi perwakilan, walaupun diakui juga ada keuntungan-keuntungannya. ${ }^{21}$ Jadi, demokrasi perwakilan yang elitis ini adalah demokrasi yang semu, hanya diperankan oleh sekelompok orang yang mengatasnamakan rakyat melalui justifikasi pemilihan umum. Dari berbagai praktek demokrasi perwakilan yang lebih diperankan oleh sekelompok elit yang duduk dalam lembaga perwakilan ini, dalam perkembangannya menuntut adanyà demokrasi partisipatoris.

Tuntutan demokrasi partisipatoris ${ }^{22}$ dalam upaya memberdayakan masyarakat untuk turut serta dalam proses pengambilan keputusan publik telah menjadi isu penting dalam konteks global dewasa ini. ${ }^{23} \mathrm{Di}$ Indonesia- yang menganut sistem demokrasiwacana tentang partisipasi masyarakat dalam proses pengambilan keputusan publik ini, telah menjadi bagian tak terpisahkan dalam proses berdemokrasi di Indonesia, dan terasa lebih meningkat terutama setelah bergulirnya gerakan reformasi $1998 .{ }^{24}$

Dengan memahami berbagai aspek yang bertalian dengan partisipasi masyarakat

${ }^{19}$ Geoffrey de Q. Walker, Initiative and Referendum : The People's Law, (The Centre for Independent Studies, Australia, 1987), hlm. 3.

${ }^{20}$ Berkaitan dengan masalah ini rakyat dianggap sudah cukup berperan dalam kehidupan negara melalui penyelenggaraan pemilihan umum yang dilakukan secara periodik dalam negara. Melalui pemillian umum, rakyat sudah melakukan hak dan kewajibannya sebagai warga negara. Dalam demokrasi perwakilan, peran rakyatdigantikan oleh sekelompok elite politik dalam melaksanakan pemerintahan. Setelah dilakukannya pemilihan umum, maka proses bernegara dalam pengambilan keputusan-keputusan publik sepenuhnya diwakili oleh lembaga perwakilan. Lembaga perwakilan ini akan menjalankan tugas dan fungsinya secara bebas tanpa dibayangi oleh kontrol dan protes dari rakyatnya.

${ }^{21}$ Robert A Dahl, Perihal Demokrasi : Menjelajahi Teori dan Praktek Secara Singkat, Penerjemah A. Rachman Zainuddin, Edisi Pertama, Yayasan Obor Indonesia, Jakarta, 2001. hlm. 157.

${ }^{2}$ Kelahiran konsep partisipasi dalam sistem demokrasi sehingga memunculkan "participatory democracy" ini, tampaknya tidak terlepas dari adanya gerakan "New Left' sebagai pengaruh dari "legitimation crisis" pada akhir dasawarsa 1960 an.. Gerakan "New Leff" yang memunculkan demokracy partisipatory ini adalah the main counter-models on the left to the legal democracy. Legal democracy bertumpu pada premis pluralist theory of politics yang mengacu kepada teori overloaded govermment, sedangkan demokrascy partisipatory bertumpu pada premis Marxist yang mengacu kepada teori legitimation cricris. Lihat David Held, Models of Democrcy, Second Edition, Polity Press, Tahun 1996, hlm. 241 dan 264.

${ }^{23}$ Gary Craig and Marjorie Mayo (Editor), loc. cit.

${ }^{24}$ Sebenamya pertama kali pemerintah mencanangkan wacana periunya partisipasi rakyat dalam pembangunan di Indonesia telah dimulai sekitar tahun 1981, akan tetapi partisipasi oleh pemerintah ketika itu dipahami sebagai kemauan rakyatuntuk mendukung program-program pemerintah yang dirancang dan ditentukan tujuannya oleh pemerintah. Pemahaman partisipasi seperti ini mengasumsikan adanya subordinasi subsistem oleh suprasistem dan bahwa subsistem adalah suatu bagian yang pasif dari sistem pembangunan nasional. Lihat Loekman Soetrisno, Menuju Masyarakat Partisipatif, Cetakan ke 6, Kanisius, Yogyakarta, 1995, hlm. 207. 
dalam melakukan kegiatan politik di atas, maka dalam demokrasi partisipatoris menuntut peran aktif berbagai komponen demokrasi secara keseluruhan. ${ }^{25}$ Demokrasi jenis ini akan memberikan peluang yang luas kepada rakyat untuk berpartisipasi secara efektif dalam proses pengambilan keputusan yang menyangkut kebijakan publik. Prinsip yang dipakai dalam demokrasi partisipatoris ini adalah persamaan bagi seluruh warga negara yang telah dewasa untuk ikut menentukan agenda dan melakukan kontrol terhadap pelaksanaan agenda yang telah diputuskan secara bersama. Hal ini dilakukan agar perjalanan kehidupan bernegara mendapatkan pemahaman yang jernih pada sasaran yang tepat dalam rangka terwujudnya pemerintahan yang baik. ${ }^{26}$ Jadi, demokrasi partisipatoris pada hakekatnya adalah demokrasi yang secara sadar akan memberdayakan rakyat dalam rangka mewujudkan pemerintahan "dari rakyat, oleh rakyat dan untuk rakyat dan bersama rakyaf". ${ }^{27}$

Adanya pemberdayaan rakyat yang berupa partisipasi langsung ini penting karena sistem perwakilan rakyat melalui lembaga perwakilan tidak pernah dapat diandalkan sebagai satu- satunya saluran aspirasi rakyat. Sebab menurut Jimly Asshiddiqie prinsip "representation in ideas" dibedakan dari "representation in presence", karena perwakilan fisik saja belum tentu mencerminkan keterwakilan gagasan atau aspirasi. ${ }^{28}$ Akhirnya, pelibatan rakyat secara aktif dalam proses penentuan agenda, pengambilan keputusan dan kontrol terhadap kebijakan yang telah diambil secara bersama, maka rakyat akan memberikan dukungan dengan penuh antusias dan dapat merasakan bahwa mereka mempunyai tingkat "ownership" yang tinggi dalam bernegara. ${ }^{29}$

Pemahaman terhadap konsep demokrasi partisipatoris tersebut, maka pada dăsarnya keberadaan lembaga perwakilan walaupun terdapat berbagai kelemahantetaplah merupakan salah satu komponen dalam demokrasi. Artinya, dinamika demokrasi modern dalam nation state selain lembaga perwakilan yang diisi melalui pemilihan umum - masih terdapat elemen demokrasi lainnya yang mempunyai hak dan kedudukan yang sama dalam penyelenggaraan pemerintahan. Di sinilah arti pentingnya, interest group, presure group, tokoh

${ }^{25}$ Komponen demokrasi adalah organ-organ kelembagaan, kekuatan-kekuatan masyarakat dan kekuatankekuatan individual yang akan saling menunjang dan melengkapi dalam berjalannya sistem demokrasi yaitu: pertama, adanya pemilihan umum yang bebas untuk mengisi lembaga perwakilan; kedua, adanya responsible govemmentkepada rakyat; ketiga, adanya kebebasan berserikat; keempat, adanya kebebasan mengeluarkan pendapat baik secara-lisan maupun tulisan; kelima, adanya peradilan yang bebas dan tidak memihak; dan keenam, adanya pendidikan kewarganegaraan.

${ }^{26}$ RobertADahl, Democracy, Yale University Press, USA, 1998.

${ }^{27}$ Jimly Asshiddiqie, Konstitusi dan Konstifusionalisme Indonesia, Cetakan Kedua, (Sekretariat Jenderal dan Kepaniteraan Mahkamah Konstitusi, Jakarta, 2006), hlm. 141.

${ }^{28}$ bid., hlm. 161

${ }^{29}$ Samuel P Huntington dan Joan Nelson, No Easy Choice Political Participation in Developing Countries, (Harvard University Press, USA, 1976). hlm. 6 
masyarakat, pers dan partai politik ${ }^{30}$ ikut ambil bagian dalam proses penyelenggaraan pemerintahan. Aktivitas dari berbagai kekuatan politik masyarakat dalam upaya mempengaruhi kebijakan publik ini merupakan input bagi suatu sistem politik yang akan diproses menjadi output dalam penyelenggaraan negara. ${ }^{31}$ Peran dari elemenelemen masyarakat ini sangat diperlukan dalam rangka menciptakan demokrasi partisipatoris, meskipun pada akhirnya di negara-negara yang telah membuka diri terhadap pendekatan sosiologis sekalipun, pembuat UU tetap yang bertanggung jawab dalam pembentukan UU. ${ }^{32}$

Meskipun telah dilakukan pembagian yang profesional antara rakyat dengan politisi yang pada gilirannya bermuara pada pentingnya kesadaran lembaga perwakilan, namun rakyat tetap harus diberikan tempat untuk bisa berpartisipasi secara aktif dalam proses pembentukan UU. Partisipasi masyarakat yang tercermin dalam berbagai kelompok-kelompok masyarakat ini dapat dilakukan melalui, misalnya : inisiatif masyarakat, public hearing, unjuk rasa, media massa, tanggapan terhadap rancangan
RUU, penyampaian terhadap kajian-kajian naskah akademik, penolakan terhadap RUU yang telah ditetapkan sebagai UU dsb. Masalahnya adalah bagaimana partisipasi masyarakat dalam proses pembentukan UU ini tidak menjadi kondisi yang anarkhis. Jadi, partisipasi masyarakat dalam pembentukan UU dalam suatu negara demokrasi ini harus dilihat secara seksama dan perlu dituangkan secara proporsional dalam suatu aturan hukum.

\section{Proses Pembentukan UU di Era Reformasi}

Perubahan tatanan politik yang mendorong proses demokratisasi dan dibarengi dengan Perubahan UUD 1945 termasuk dalam lembaga legislatif, telah melahirkan berbagai perbedaan pokok dalam proses pembentukan UU dalam era reformasi ini apabila dibandingkan dengan masa Orde Baru. Pada masa Orde Baru keberadaan DPR lebih merupakan perpanjangan tangan Pemerintah sehingga dalam proses pembentukan UU Pemerintah lebih dominan.

${ }^{30}$ Kekuatan-kekuatan politik ini merupakan kekuatan infrastruktur politik yang perlu diberikan tempat secara proporsional dalam sistem demokrasi partisipatoris. Kekuatan infrastruktur politik ini akan melakukan partisipasi dalam berbagai bentuk-bentuk partisipasi politik yang dapat berupa konvensional maupun non konvensional. Partisipasi politik yang konvensional adalah : pemberian suara (voting), diskusi politik, kegiatan kampanye, membentuk dan bergabung dalam kelompok kepentingan, komunikasi individual dengan pejabat politik dan administratif. Sedangkan partisipasi politik yang non konvensional adalah pengajuan petisi, berdemontrasi, konfrontasi, mogok, tindak kekerasan politik terhadap harta benda, tindakan kekerasan politik terhadap manusia maupun perang gerilya dan revolusi. Lihat Gabriel AAlmond, Sosialisasi, Kebudayaan dan Partisipasi Politik, diedit oleh Mochtar Mas'oed dan Collin Mc Andrews dalam Perbandingan Sistem Politik, (Gajah Mada University Press, Cetakan Keenambelas, Yogyakarta, 2001), him. 45-46.

${ }^{31}$ David Easton, A Framework for Political Analysis, (Cetakan Kesepuluh, Printice Hall, Inc., englewood Cliffs, N J, United States of America, 1965), hlm. 112.

32Jufrina Rizal, Sosiologi Perundang-undangan, makalah yang disajikan dalam Pendidikan dan Latihan Tenaga Tehnis Perundang-undangan Sekretariat Jenderal DPR RI, Jakarta, 1998/1999, hlm. 7. 
Hal ini karena sistem politik yang dibangun oleh Orde Baru telah melahirkan dominasi kekuatan politik Golongan Karya yang merupakan pendukung Permerintah dan juga sebagai kekuatan mayoritas dalam DPR sehingga sangat berpengaruh dalam proses pembentukan UU.

Proses pembentukan UU pada masa Orde Baru tersebut, berbeda secara kontras dengan proses pembentukan UU di era reformasi. Perbedaan dalam proses pembentukan UU di era reformasi ini dapat dilihat, baik dari sisi kelembagaan DPR, sisi kepentingan masyarakat maupun sisi pembahasan RUUnya. Dari sudut pandang kelembagaan DPR, berbagai perbedaan pokok yang tampak dalam proses pembentukan UU di era reformasi ini adalah : pertama, dasar konstitusionalnya yang lebih kuat; kedua, peran legislasi lebih tegas; ketiga, produk UUnya banyak yang berasal dari usul inisiatif DPR.33 dan keempat, eksekutif tidak lagi dominan dalam proses pembentukan UU. ${ }^{34}$ Sementara itu dilihat dari sisi kepentingan masyarakat, perbedaan yang tampak dalam proses pembentukan UU di era reformasi ini ada dua hal pokok yaitu : pertama, masyarakat lebih bebas untuk berekspresi dalam memantau rapat-rapat pembahasan pembentukan UU baik melalui media maupun secara langsung datang ke DPR; kedua, antara masyarakat dan wakil rakyat yang duduk di DPR dapat terjadi kontak yang lebih intensif sebagai hasil hubungan yang dibangun secara terbuka layaknya hubungan pertemanan. ${ }^{35}$
Sedangkan dari sisi pembahasan RUUnya terlihat bahwa pembahasan secara intensif, mendalam dan menyeluruh terhadap suatu RUU dilakukan dalam Rapat Komisi, Rapat: Pansus maupun Rapat Panitia Kerja. Meskipun demikian, tidak mudah untuk mencapai terwujudnya persamaan dalam memandang suatu persoalan yang akan diatur dalam suatu RUU. Hal ini karena dalam pembahasan terjadi pengkajian yang bertalian dengan tata nilai dan kepentingan yang dibawa oleh berbagai kekuatan politik. Oleh karena itu, suatu produk UU dilihat dari konteks sosial masyarakat lebih merupakan endapan konflik niali dan kepentingan yang secara politik diputus oleh lembaga legislatif, dan jika tidak dibüat secara hati-hati dapat menimbulkan masalah baru di kemudian hari.

Perlu juga dikemukakan bahwa persoalan yang spesifik dalam proses pembentukan UU dalam era reformasi adalah adanya kesadaran dan jaminan secara normatif dalam Peraturan Tata Tertib DPR. Meskipun demikian, partisipasi masyarakat ini sebenarnyas telah ada sejak Orde Baru dan terasa meningkat pada era reformasi. Hal ini terlihat dengan adanya Rapat Dengar Pendapat Umum (RDPU) dalam Peraturan Tata Tertib DPR RI No. 03A Tahun 2001/2002; dan adanya RDPU serta jaminan akan hak masyarakat untuk memberikan masukan secara lisan dan tertulis dalam proses pembentukan UU yang terdapat dalam Peraturan Tata Tertib DPR RI No. 15 Tahun $2004 / 2005$.

\footnotetext{
${ }^{33} \mathrm{Hasil}$ wawancara dengan Mutammimul Ula dari Fraksi PKS tanggal 17 Mei 2005 di DPR.

${ }^{34} \mathrm{Hasil}$ wawancara dengan Apri Hananto Sukandar Ketua Fraksi PDS di DPR tanggal 16 Mei 2005.

${ }^{35} \mathrm{Hasil}$ wawancara dengan Bivitri Susanti Direktur Eksekutif Pusat Studi Hukum dan Kebijakan (PSHK) Indonesia tanggal 23 Mei 2004 di PSHKKuningan Jakarta.
} 
Penyerapan partisipasi masyarakat dalam proses pembentukan UU ini terlihat dalam menanggapi masukan, kritik dan saran dari berbagai kalangan dalam proses pembahasan RUU diserahkan lagi kepada Anggota Panitia Kerja ${ }^{36}$ Ini berarti bahwa segala macam masukan-masukan dibahas kembali sebagai penyerap dari aspirasi masyarakat. ${ }^{37}$ Dengan demikian, respon-respon yang ada harus dikelola dengan baik, dilembagakan sebagai proses hidup berbangsa. ${ }^{38}$ Akan tetapi, Panitia Kerja yang dibentuk oleh alat kelengkapan $\mathrm{DPR}{ }^{39}$ keanggotaannya ditunjuk oleh Fraksi yang jumlahnya sedapat mungkin sesuai dengan jumlah Anggota tiap-tiap Fraksi. ${ }^{40}$ Untuk ini, Fraksi akan memantau Anggotanya dengan mengadakan Rapat Fraksi yang dijadualkan pada setiap hari Jumat. ${ }^{41}$ Sebagai contoh dari ketundukan Anggota DPR terhadap garis kebijakan Fraksi ini adalah ketidakhadiran Fraksi PDIP dalam Pembicaraan Tingkat II pengambilan keputusan tentang RUU
Sisdiknas dalam Rapat Paripurna tanggal 11 Juni $2003 .^{42}$

Atas uraian di atas, maka persoalan mendasar berkaitan dengan penyerapan partisipasi masyarakat dalam : proses pembentukan UU adalah bagaimana hubungan antara si wakil dengan yang diwakili. Artinya, untuk mengkaji persoalan penyerapan aspirasi masyarakat baik yang dilakukan secara langsung datang ke DPR, atau atas permintaan DPR, atau melalui media, dan atau melalui unjuk rasa, maka akan sampai pada kajian teori dalam melihat apakah si wakil itu bertindak atas nama diri sendiri, atau bertindak atas nama kelompok/golongan atau atas nama rakyat secara langsung. Dengan kata lain, proses penyerapan tuntutan dari partisipasi masyarakat akan sangat tergantung dari sistem pemilu yang dipakai dalam mengisi lembaga perwakilan. ${ }^{43}$

Pada akhirnya, dapat dikemukakan bahwa dengan melihat pada berbagai

\footnotetext{
${ }^{36}$ Sekretariat Jenderal DPR R!, Proses Pembahasan RUU Tentang Sistem Pendidikan Nasional, Jakarta, 2003, hlm. 2347.

${ }^{37}$ Sekretariat Jenderal DPR RI, Proses Pembahasan RUU Tentang Sistem Pendidikan Nasional, ibid. hlm. 2657.

${ }^{38}$ Sekretariat Jenderal DPR RI, Proses Pembahasan RUU Tentang Sistem Pendidikan Nasional, ibid.

39Lihat Pasal 61 Peraturan Tata Tertib DPR RINo. 03A03A/DPR RI//2001-2002 tentang Peraturan Tata Tertib DPR RI, hlm. 60. Lihat pula Pasal 67 Peraturan Tata Tertib DPR RINo. 15/DPR RI///2004-200, hlm. 32.

${ }^{40}$ Lihat Pasal 68 Peraturan Tata Tertib DPR RI No. 15/DPR RI//2004-2005, ibid.

${ }^{41} \mathrm{H}$ asil wawancara dengan Apri Hananto Sukandar Ketua Fraksi PDS di DPR tanggal 16 Mei 2005.

${ }^{42}$ Sekretariat Jenderal DPR RI, Proses Pembahasan RUU Tentang Sistem Pendidikan Nasional ...op. cit., hlm. 2993. Keputusan DPR No. 15/DPR RI/I/2004-2005 tentang Peraturan Tata Tertib DPR.

${ }^{43}$ Sistem Pemilu yang secara umum banyak dipakai adalah sistem pemilihan distrik dan sistem pemilihan proporsional. Sebagai suatu sistem, maka baik sistem distrik maupun sistem proporsional mempunyaikekuatan dan kelemahan masing-masing. Oleh karena itu sistem pemilhan umum tidak ada yang sempurna. Negara yang semula menganut sistem distrik dalam perkembangannya mengubah ke sistem proporsional, sebaliknya Negara yang semula menerapkan sistem proporsional dalam perkembangannya mengubah ke sistem distrik. Lihat Jimly Asshiddiqie dalam "Masukan Pakar yang Khusus Diundang Dalam Penyusunan RUU Pemilu", Risalah Sekretariat Pansus Pemilu 3 September 2002.
} 
pengaturan yang berkaitan dengan penyerapan partisipasi masyarakat dalam berbagai Peraturan Tata Tertib DPR dan dikaitkan dengan temuan dalam penelitian di lapangan serta mengacu pada model-model teori yang ada dalam melihat hubungan antara si wakil dengan yang diwakili, maka tampak bahwa praktek representasi politik di DPR lebih dekat pada teori Gilbert Abcarian khususnya model keempat yaitu si wakil bertindak sebagai "partisan". Artinya si wakil bertindak sesuai dengan keinginan atau program dari partai (organisasi) si wakil. Setelah si wakil dipilih oleh pemilihnya, maka lepaslah hubungan dengan pemilih dan mulailah hubungan dengan partai (organisasi) yang mencalonkannya. ${ }^{44}$ Hal ini karena sejak awal Anggota DPR yang masuk sebagai Anggota Panitia Kerja suatu RUU telah dibekali garis kebijakan Fraksi, dan dikontrol oleh Fraksi melalui rapat-rapat Fraksi yang secara rutin dilakukan pada setiap hari Jumat ${ }^{45}$ serta pandangan dan pendapat terhadap suatu RUU adalah atas nama Fraksi. ${ }^{46}$

\section{Partisipasi Masyarakat Dalam Proses Pembentukan UU Sisdiknas, UU Pemilu dan UU Ketenagakerjaan}

Di era reformasi, adanya partisipasi masyarakat dalam proses pembentukan UU terasa meningkat seiring dengan perubahan tatanan politik pasca runtuhnya Orde Baru. $\mathrm{Hal}$ ini terlihat dari adanya partisipasi masyarakat dalam proses pembentukan UU yang dilakukan sebagai contoh penelitian yaitu : UU Sisdiknas, UU Pemilu dan UU Ketenagakerjaan. Partisipasi masyarakat dalam proses ketiga UU tersebut, dapat didentifikasi dalam hạ : pelaku partisipasi, cara menyampaikan partisipasi, bentuk-bentuk partisipasi, materi yang diusung dalam partisipasi, dan tindak lanjut partisipasi masyarakat dalam lembaga legislatif. Pada kesempatan ini hanya akan disajikan analisis secara singkat berdasarkan temuan penelitian yang telah dikemukakan di muka :

\section{a. Pelaku Partisipasi Masyarakat Dalam Proses Pembentukan UU}

Dalam proses pembentukan UU Sisdiknas, UU Pemilu dan UU Ketenagakerjaan yang dijadikan contoh penelitian, ditemukan adanya berbagai elemen masyarakat baik secara individual maupun kelompok yang menyampaikan aspirasinya guna mempengaruhi proses pengambilan kebijakan publik di lembaga perwakilan. Sikap masyarakat ini dapat berupa dukungan, penolakan maupun masukan terhadap suatu RUU. Dukungan masyarakat adalah suatu sikap setuju dengan langkah yang diambil oleh partai politik dalam memperjuangkan aspirasinya dalam suatu UU. Penolakan masyarakat adalah sikap ketidaksetujuan terhadap adanya suatu UU karena tidak sesuai dengan aspirasi yang diinginkannya. Sementara itu masukan masyarakat adalah berbagai pemikiran yang

\footnotetext{
${ }^{4}$ Moh Kusnardi dan Bintan R Saragih, Umu Negara, Cetakan Ketiga, Gaya Media Pratama, Jakarta, 1995.

${ }^{45}$ Hasil wawancara dengan ApriAnanto Sukandar Ketua Fraksi PDS di DPR tanggal 16 Mei 2005.

${ }^{46}$ Terhadap persoalan yang sangat prinsipiil bagi. Fraksi, maka Anggota Panitia Kerja akan menunda .. terlebih dulu untuk konsultasi dengan Fraksi.
} 
disumbangkan dalam rangka memperbaiki dan menyempurnakan suatu RUU.

Terhadap tiga UU yang diteliti dan terbatas pada sumber-sumber tertentu, ${ }^{47}$ terdapat 355 aktivitas kegiatan partisipasi masyarakat baik berupa dukungan, penolakan maupun masukan yang dilakukan untuk mempengaruhi proses pembahasan suatu RUU. Adanya partisipasi masyarakat ini ditujukan agar produk UU yang dikeluarkan oleh lembaga pembentuk UU sesuai dengan aspirasi masyarakat.

Dari data yang ditemukan terlihat bahwa secara keseluruhan dari tiga UU yang diteliti, "pengamat \& pakar" menduduki tempat terbanyak dengan jumlah 94 kali. Sedangkan jumlah partisipasi yang paling sedikit dilakukan oleh "partai politik" yang tidak duduk di DPR yaitu 2 kali. Hal ini dapat dijelaskan bahwa "pengamat \& pakar" sebagai orang yang mempunyai pengetahuan luas terhadap suatu persoalan yang tengah dibahas dan didukung oleh kebebasan dalam mengeluarkan pikiran dan pendapatnya memainkan peran yang besar dalam membentuk opini publik, sehingga akan terjadi penyebaran informasi kepada masyarakat secara luas terhadap suatu materi yang sedang diproses dalam lembaga legislatif. Sementara itu sedikitnya partai politik berpartisipasi, adalah karena partai politik yang dapat menempatkan wakilnya di lembaga perwakilan sudah secara langsung terlibat dalam proses pembentukan UU di lembaga legislatif. Sedangkan partai politik yang tidak dapat menempatkan wakilnya di lembaga perwakilan ada kecenderungan tengah melakukan konsolidasi internal partai dan baru terlibat berpartisipasi ketika kepentingannya diabaikan. Jadi, dapat dipahami bahwa "pengamat \& pakar" yang tidak terlibat secara langsung dalam proses pembentukan UU akan menyampaikan aspirasinya melalui sarana media cetak yang dijamin kebebasannya. Sementara itu "partai politik" yang melakukan partisipasi adalah partai politik yang tidak mendapat tempat dalam lembaga perwakilan dan perlu konsolidasi dalam rangka menghadapi pemilihan umum berikutnya.

Akan tetapi jika dilihat secara masingmasing UU, tampak bahwa untuk UU Sisdiknas partisipasi terbanyak dilakukan oleh "pengamat \& pakar" yang mencapai 38 kali, sementara yang paling sedikit dilakukan oleh "organisasi politik" yaitu 1 kali. Untuk UU Pemilu jumlah partisipasi terbanyak dilakukan oleh "pers" yang mencapai 67 kăli, $^{48}$ sedangkan jumlah paling sedikit dilakukan oleh "kelompok professional" dengan hanya 1 kali. Kemudian untuk UU Ketenagakerjaan jumlah partisipasi terbanyak dilakukan oleh "organisai serikat pekerja" dengan total 33 kali, sedangkan paling sedikit dilakukan oleh "perguruan tinggi, perorangan/tokoh masyarakat dan kelompok professional" dengan masing-masing 1 kali. Dari berbagai elemen masyarakat sebagai pelaku partisipasi tersebut tampak bahwa ada pelaku yang selalu

\footnotetext{
${ }^{47}$ Jumlah 355 aktifitas kegiatan dari partisipasi masyarakat terhadap 3 proses pembentukan UU ini adalah terbatas pada sumber tertentu yang diambilkan dari Perpustakaan CSIS Jakarta dan Perpustakaan Kompas Jakarta serta Lampiran Laporan Sekretariat Jenderal DPRRI Tahun Sidang 2002-2003.

${ }^{49}$ Pers di sini maksudnya adalah berupa tajuk dan tulisan yang dibuat oleh wartawan dari surat kabar yang bersangkutan terhadap materi yang tengah dibahas dalam suatu RUU.
} 
tampil dalam setiap proses pembentukan UU, yaitu, Perguruan Tinggi, pengamat \& pakar, kelompok professional, LSM, pers dan perorangan/tokoh masyarakat. Di antara pelaku partisipasi masyarakat yang selalu muncul dalam ketiga UU yang diteliti, partisipasi terbanyak dilakukan oleh "pengamat \& pakar", sedangkan pelaku partisipasi lainnya jumlahnya sangat kecil. Selain ada pelaku partisipasi masyarakat yang selalu tampil dalam ketiga UU, ada pula pelaku yang hanya muncul sesuai dengan materi UU yang dibuatnya, yaitu, "utusan kedaerahan, organisasi serikat pekerja dan pengusaha". Pelaku-pelaku partisipasi masyarakat ini hanya tertarik memberikan partisipasinya ketika ada kepentingan di dalamnya.

Dari temuan di atas menarik untuk dilihat lebih.jauh yaitu mengapa untuk UU Sisdiknas yang tertinggi dilakukan oleh "utusan kedaerahan," UU Pemilu oleh "pers" dan UU Ketenagakerjaan oleh "organisasi serikat pekerja" ?

Pertama, untuk UU Sisdiknas kaitannya dengan "utusan kedaerahan". Sebagaimana diketahui isu utama dalam proses pembentukan RUU Sisdiknas adalah menyangkut masalah yang berkaitan dengan agama bagi peserta didik. Persoalan agama ini mencuat karena adanya ketentuan Pasal 12 ayat (1) butir 1 RUU Sisdiknas yang pada pokoknya menegaskan bahwa "setiap peserta didik berhak memperoleh pendidikan agama sesuai dengan agamanya dan diajarkan oleh guru yang seagama.

Adanya ketentuan pasal tersebut melahirkan pro maupun kontra dalam mensikapi terhadap proses pembahasan RUU Sisdiknas di tengah-tengah masyarakat.
Bagi kalangan ummat Islam sebagai kelompok yang mendukung, adanya ketentuan tersebut disyukuri dan mutlak harus didukung, karena berkaitan dengan hakekat kehidupan yang sangat fundamental. Agama bagi ummat Islam adalah segalanya sehingga perpindahan agama merupakan pemurtadan dan termasuk kategori dosa besar yang tidak diampuni oleh Allah SWT. Akan tetapi bagi umat Katolik dan Kristen adanya Pasal 12 ayat (1) butir 1 tersebut dianggap sebagai upaya campur tangan Negara terhadap masalah HAM. Dari kalangan yang kontra, persoalan agama merupakan masalah HAM dan oleh karenanya negara dilarang campur tangan terhadap HAM karena menyangkut persoalan individu. Oleh karena itu, berbagai cara dilakukan untuk menolak dimasukkannya Pasal 12 ayat (1) butir. 1 tersebut dalam RUU Sisdiknas. Salah satu cara yang dilakukan adalah mengirimkan utusan yang bersifat kedaerahan dari daerah-daerah yang mayoritas penduduknya beragama Nasrani, seperti dari Manado, NTT, Kepulauan Nias dan Papua dll. Di sinilah persoalannya mengapa "utusan kedaerahan" menempati jumlah terbanyak dalam melakukan aksi penolakan terhadap pembahasan RUU Sisdiknas.

Kedua, untuk UU Pemilu jumlah terbanyak ditempati oleh "pers" melalui media cetak yang berupa surat kabar maupun majalah. Hal ini dapat dipahami dengan melihat "pers" sebagai salah satu pilar demokrasi selain lembaga perwakilan, lembaga eksekutif dan lembaga yudikatif. ${ }^{49}$ UU Pemilu merupakan pintu gerbang dalam membangun demokrasi, maka pembentukan UU ini mengundang

${ }^{49}$ Moh Mahfud MD, Politik ... loc. cit. 
perhatian "pers" untuk ikut meramaikan dalam proses pembentukannya. "Pers" berfungsi sebagai lembaga kontrol sosial membuka peluang yang besar dalam menginformasikan dialektika masyarakat dalam memperiuas wacana berkaitan dengan suatu persoalan termasuk masalah RUU Pemilu.

Oleh karena itu, tidak mengherankan jika dalam pembentukan UU Pemilu ini "pers" menempati jumlah terbanyak hingga mencapai 67 kali partisipasinya. Apabila ditambah dengan peran "pers" yang memuat berbagai artikel dari pengamat dan pakar yang berjumlah 40 kali dan penyebar luasan kegiatan LSM sebanyak 8 kali, maka total keseluruhan aktivitas partisipasi masyarakat yang dilakukan oleh "pers" akan mencapai 115 kali. Suatu jumlah yang relatif tinggi tingkat partisipasinya dalam suatu Negara yang sedang memasuki transisi menuju negara demokrasi.

Ketiga, berkaitan dengan UU Ketenagakerjaan terlihat bahwa partisipasi terbanyak dilakukan oleh "organisasi serikat pekerja" yang mencapai jumlah 33 kali. Kenyataan ini menunjukkan bahwa pekerja melalui organisasi-organisasi serikat kerjanya melakukan perjuangan yang gigih dalam memperjuangkan aspirasi yang berkaitan dengan kepentingan pekerja. Usaha dalam mempengaruhi lembaga legislatif ini, dilakukan baik melalui statemen-statemen tentang penolakan terhadap RUU Ketenagakerjaań, maupun dengan unjuk rasa mengerahkan ratusan bahkan ribuan buruh dengan membawa berbagai poster yang pada dasarnya menolak RUU Ketenagakerjaan.

Atas dasar uraian diatas, maka dalam proses pembentukan UU Ketenagakerjaan "organisasi serikat pekerja" sangat efektif dalam.melakukan konsolidasi untuk menggerakkan buruh melakukan berbagai aktivitas dalam menyuarakan aspirasi tuntutannya. Dalam kenyataannya hal ini merupakan suatu tekanan yang kuat guna menekan lembaga legislatif agar menampung, mempertimbangkan dan pada gilirannya menerima sebagai bahan masukan perumusan materi RUU Ketenagakerjaan. Jadi, keberadaan "serikat pekerja" di perusahaanperusahaan benar-benar sangat dibutuhkan dan berguna dalam memperjuangkan kepentingan buruh sebagai pihak yang lemah, tidak saja dalam menghadapi pengusaha sebagai pihak yang kuat tetapi juga ketika buruh menghadapi elit politik di lembaga legislatif.

Dengan melihat pada tabel dan uraian di atas, maka tingkat partisipasi masyarakat dalam proses pembentukan UU terhadap UU Sisdiknas, UU Pemilu dan UU Ketenagakerjaan adalah cukup tinggi. Tingkat partisipasi masyarakat yang cukup tinggi ini dapat djelaskan dari berbagai sudut pandang :

Pertama, dari teori J.L.A. Hart yang mengemukakan bahwa dalam memahami sumber hukum dikenal adanya primary rules dan secondary rules. ${ }^{50}$ Dalam kaitan ini, lembaga legislatif merupakan sumber kedua

${ }^{50}$ Primary rules pada dasarnya adalah aturan yang hidup di tengah-tengah masyarakat sebagai sumber utama suatu aturan hukum. Sedangkan secondary rules pada pokoknya adalah suatu aturan hukum yang. diproduk oleh lembaga legislatifPrimary rules pada dasarnya adalah aturan yang hidup di tengah-tengah - masyarakat sebagai sumber utama suatu aturan hukum. Sedangkan secondary nules pada pokoknya adalah suatu aturan hukum yang diproduk oleh lembaga legislatif Hari Chan, Modem Jurisprudence, Intemational Law Book Services, Kuala Lumpur, 1994, hlm. 83-90. 
(secondary rules) dalam pembentukan UU, sedangkan masyarakat menempati sumber utama (primary rules) dalam pembentukan UU. Dengan demikian adanya partisipasi masyarakat dalam pembentukan UU ini dikarenakan adanya tatanan nilai yang oleh masyarakat dianggapa benar. dan belum tertampung dalam suatu RUU yang tengah dibahas oleh lembaga legislatif.

Kedua, dilihat dari pemikiran David Aston tentang adanya faktor lingkungan internal dan faktor lingkungan eksternal yang mendorong adanya partisipasi masyarakat yang tidak terlepas dari proses input-output suatu sistem politik. ${ }^{51}$ Pertama, respon yang diberikan masyarakat terhadap proses pembentukan UU Sisdiknas lebih merupakan dipengaruhi oleh faktor internal, khususnya berkaitan dengan personality system dan social system. Personality system bertalian dengan tatanan nilai agama yang dianut oleh suatu individu warga negara, sementara social system bertalian dengan tatanan lingkungan sosial masyarakat, di mana di indonesia di kenal adanya lima agama besar yang dianut oleh masyarakat. Kedua, tanggapan yang disampaikan. masyarakat terhadap proses pembentukan UU Pemilu tampaknya disebabkan faktor internal dan eksternal. Faktor internal, khususnya social system dalam bentuk adanya perubahan tatanan sosial sebagai akibat adanya gerakan reformasi yang pada dasarnya menuntut pemberdayaan rakyat dalam suatu negara pasca runtuhnya Orde Baru. Sementara itu faktor eksternal muncul sebagai pengaruh lingkungan internasional yang secara global menuntut adanya demokratisasi yang lebih memberikan pemberdayaan rakyat dalam proses bernegara. Ketiga, respon masyarakat terhadap proses pembentukan UU Ketenagakerjaan tidak terlepas dari faktor internal dan eksternal. Faktor intemal berupa faktor social system yang muncul tidak hanya dari solidaritas tatanan masyarakat pekerja karena: merasa kepentingannya dirugikan dalam pembentukan UU Ketenagakerjaan, tetapi juga kepentingan pemerintah untuk dapat menciptakan lapangan kerja guna mengatasi masalah pengangguran yang terus bertambah. Sementara dari faktor eksternal muncul berupa tuntutan dari penanam modal asing untuk dapat menanamkan modalnya di Indonesia dengan berbagai fasilitas yang menguntungkan pengusaha namun merugikan kaum buruh."

Ketiga, dilihat dari teori demokrasi yang berdasarkan atas hukum menutut adanya persamaan dan kebebasan rakyat sesuai dengan ketentuan peraturan perundangundangan. Sebagaimana diketahui, hasil kongkrit reformasi adalah terwujudnya tatanan yang lebih demokratis dalam proses politik pasca runtuhnya Orde Baru. Kondisi politik ini, selanjutnya dituangkan dalam Perubahan UUD 1945 sebagai landasan konstitusiona! tertinggi dalam negara. Berkaitan dengan partisipasi masyarakat ini, ternyata secara tersirat memperoleh landasan konstitusionalnya dalam Perubahan UUD 1945 yaitu pada aspek penegasan kedaulatan rakyat dan kebebasan dalam menyatakan pikiran dan pendapatnya. Dengan demikian, adanya partisipasi masyarakat dalam proses pembentukan UU ini merupakan salah satu dari aplikasi dari jaminan demokrasi yang memperoleh landasan konstitusionalnya dalam Perubahan UUD 1945.

${ }^{51}$ David Easton, 1oc. cit. 
Cara Menyampaikan Partisipasi Masyarakat dalam Proses Pembentukan UU

Dalam proses pembentukan RUU Sisdiknas, RUU Pemilu dan RUU Ketenagakerjaan terdapat berbagai cara yang ditempuh oleh pelaku partisipasi masyarakat dálam upaya mempengaruhi lembaga legislatif agar partisipasinya diterima. Dari 355 kali partisipasi yang dilakukan dalam proses pembentukan ketiga UU tersebut, cara yang ditempuh dapat dikelompokkan dalam tiga kegiatan, yaitu, sbb: langsung datang ke DPR melalui rapat dengar pendapat umum (RDPU) sebanyak 85 kali; secara tidak langsung melalui media cetak 248 kali; dan dilakukan dengan unjuk rasa 22 kali.

Pertama, bagi masyarakat yang memilih cara berpartisipasi secara langsung datang ke DPR, tampak bahwa untuk RUU Sisdiknas menempati urutan terbanyak dengan 65 kali, kemudian RUU Pemilu sebanyak 11 kali dan RUU Ketenagakerjaan mendapatkan 9 kali. Persoalannya adalah. mengapa RUU Sisdiknas memperoleh jumlah tertinggi dibandingkan dengan dua RUU yang lain ? Tampaknya hal ini tidak terlepas dari isu yang mencuat dalam proses pembentukan UU Sisdiknas yaitu persoalan agama. Persoalan agama inị merupakan masalah yang fundamental bagi hidup dan kehidupan seseorang maupun kelompok masyarakat. Oleh karena itu, bisa dipahami jika berbagai elemen masyarakat secara perorangan maupun kelembagan baik yang berasal dari kelompok keagamaan dan utusan kedaerahan memilih cara datang langsung untuk menemui Pimpinan DPR, Ketua Komisi maupun Ketua Panitia Kerja untuk menyampaikan aspirasinya. Dengan datang langsung ke DPR dan berdialog dengan fungsionaris DPR yang membidanginya maka permasalahan akan langsung didengar dan dihàrapkan akan diperjuangkan dengan sungguh-sungguh oleh wakil-wakil rakyat di DPR. Sementara itu, untuk dua RUU lainnya yaitu RUU Pemilu dan RUU Ketenagakerjaan penyampaian partisipasi masyarakat yang datang langsung ke DPR ini hanya dilakukan masing-masing 11 dan 9 kali. Ini berarti bahwa hanya sebagian masyarakat yang tertarik untuk berdialog secara langsung dengan fungsionaris DPR. Akan tetapi, untuk RUU Pemilu dan RUU Ketenagakerjaan masyarakat justeru memilih cara lain dalam menunjukkan partisipasinya dalam proses pembentukan UU, yaitu, melalui media cetak maupun dengan unjuk rasa.

Kedua, cara penyampaian partisipasi masyarakat melalui media cetak baik surat kabar maupun majalah tampaknya lebih praktis dan mempunyai jangkauan pengaruh yang luas dalam membentuk opini masyarakat. Penggunaan media cetak sebagai sarana untuk berpartisipasi dalam proses pembentukan UU ini dilakukan oleh berbagai elemen masyarakat seperti pengamat \& pakar, perguruan tinggi, kelompok professional, LSM dsb. Hal ini menunjukkan bahwa dalam era reformasi sekarang ini media cetak merupakan sarana yang effektif untuk menyampaikan gagasan-gagasannya dalam kaitan dengan pembentukan UU.

Dalam proses pembahasan RUU Sisdiknas, RUU Pemilu dan RUU Ketenagakerjaan , tampak bahwa media cetak menempati urutan terbanyak di masing-masing proses pembentukan UU, yaitu, 68 kali untuk RUU Sisdiknas, 112 kali untuk RUU Pemilu dan 68 kali untuk RUU Ketenagakerjaan. 
Penggunaan media cetak sebagai sarana penyampaian partisipasinya ini menunjukkan bahwa pelaku partisipasi masyarakat adalah sebagian besar dari kalangan intelektual yang tersebar dalam berbagai status sosial masyarakat yang sadar akan tanggung jawabnyạ terhadap persoalan yang muncul di masyarakat sesuai dengan bidangnya masing-masing.

Ketiga, cara penyampaian partisipasi masyarakat melalui unjuk rasa untuk memberikan tekanan kepada lembaga legislatif secara langsung agar keinginan dan kepentingannya diterima. Dalam penggunaan cara unjuk rasa ini terlihat bahwa dari total keseluruhan sebanyak 22 kali ditempati oleh RUU Sisdiknas 9 kali, RUU Pemilu kosong, RUU Ketenagakerjaan 13 kali. Dari kenyataan tersebut, menarik untuk dibahas lebih lanjut adalah mengapa cara penyampaian unjuk rasa ini tertinggi ada pada RUU Ketenagakejaan? Persoalan ini tidak dapat dilepaskan dari keberadaan dan lingkungan sosial buruh yäng melatar belakanginya. Sebagaimana diketahui, pada umumnya tingkat pendidikan buruh relatif tergolong rendah dan menengah. Memang terdapat juga yang berpendidikan tinggi bahkan sampai tingkat pasca sarjana, tetapi jumlahnya tidak banyak. Selain itu pada umumnya buruh relatif berpendapatan rendah, meskipun ada pula yang pendapatannya menengah dan tinggi. Adanya latar belakang keterbatasan sosial ekonomi yang melekat pada buruh inilah, sehingga membuat buruh mempunyai solidaritas yang kuat dan mudah untuk digerakkan guna memperjuangkan nasibnya. Di sinilah permasalahannya mengapa partisipasi masyarakat yang dilakukan oleh buruh melalui unjuk rasa relatif tinggi bila dibandingkan dengan unjuk rasa terhadap RUU Sisdiknas maupun RUU Pemilu.

\section{Bentuk-bentuk Partisipasi Masyarakat Dalam Proses Pembentukan UU}

Bentuk atau wujud partisipasi masyarakat dalam proses pembahasan RUU ada beraneka ragam sesuai dengan tingkat potensi dan kemampuan yang dimilikinya. Dalam proses pembahasan RUU Sisdiknas, RUU Pemilu dan RUU Ketenagakerjaan yang dijadikan contoh penelitian, tampak bahwa dari 355 kali partisipasi yang dilakukan oleh masyarakat secara umum dapat dikelompokkan dalam 6 bentuk atau wujud partisipasi masyarakat. Ada enam bentuk partisipasi masyarakat dalam proses pembentukan UU yang ditemukan dalam penelitian yaitu : i. usulan dibuatnya UU; ii. penyampaian RUU alternatif; iii. tanggapan tertulis berupa opini, kritik maupun masukan terhadap RUU; iv. penolakan atau dukungan terhadap RUU; v. penyampaian aspirasil pernasalahan berkaitan dengan RUU; vi. posterposter dalam unjuk rasa baik dukungan maupun penolakan.

Secara keseluruhan untuk ketiga UU terlihat bentuk partisipasi terbanyak adalah "tanggapan tertulis berupa opini, kritik maupun masukan terhadap RUU" yang berjumlah 206 kali, sedangkan bentuk partisipasi yang paling sedikit dilakukan masyarakat adalah "penyampaian RUU alternatif" yang hanya sebanyak 4 kali. Dengan jumlah angka 206 untuk bentuk partisipasi yang berupa tanggapan tertulis berupa opini, kritik maupun masukan terhadap RUU" dari total keseluruhan 355 partisipasi masyarakat,- maka hal ini memberikan gambaran kepada kita bahwa masyarakat lebih suka berpartisipasi secara tidak langsung dalam proses pembahasan RUU. Dengan kata lain, masyarakat lebih memilih berpartisipasi melalui media cetak 
dari pada berpartisipasi secara langsung datang ke DPR dengan cara rapat dengar pendapat umum (RDPU).

Apabila bentuk partisipasi yang berupa "tanggapan tertulis berupa opini, kritik maupun masukan terhadap RUU" menempati jumlah terbanyak hingga 206 kali, maka secara kontras sangat berbeda dengan bentuk partisipasi yang berupa "penyampaian RUU alternatif" yang hanya ada 4 kali. Persoalannya adalah apa sebab masyarakat kurang menggunakan bentuk partisipasi berupa "penyampaian RUU alternatif" ? Berkaitan dengan masalah ini berbagai kesulitan dalam membuat RUU alternatif adalah sbb. :

Kesulitan pertama, terletak pada kenyataan bahwa kegiatan pembentukan UU adalah suatu bentuk komunikasi antara perancang dengan masyarakat yang akan terkena produk UU. Tidak mudah untuk merumuskan persoalan yang kompleks dalam realitas kehidupan masyarakat dalam suatu bahasa hukum yang normatif dan dapat diterima banyak pihak. Karena masalahnya terletak pada persoalan bagaimana merumuskan aturan yang berkeadilan. Jadi, faktor yang pertama ini lebih terkait dengan aspek filosofis dalam pembentukan UU.

Kesulitan kedua dalam pembuatan RUU adalah pada adanya transformasi visi, misi dan nilai yang diinginkan oleh perancang dengan masyarakat dalam bentuk aturan hukum. Persoalan ini akan membawa pada adanya ukuran-ukuran yang jelas sebagai suatu kaidah hukum dalam penerapannya dalam masyarakat. Sebab, masalah transformasi visi, misi dan nilai ke dalam kaidah hukum ini, pada gilirannya akan menuntut kepada suatu UU untuk dapat memenuhi kebutuhan : a). mampu untuk dilaksanakan; b). mampu untuk ditegakkan; c). sesuai dengan prinsip-prinsip persamaan hakhak yang diatur; d). sesuai dengan aspirasi masyarakat. ${ }^{52}$ Masalah kesulitan yang kedua ini pada hakekatnya adalah kesulitan dalam mewujudkan adanya kepastian dan kepatuhan hukum di masyarakat. Dengan kata lain, persoalannya adalah berkaitan dengan dasar yuridis suatu UU.

Kesulitan ketiga dalam membuat RUU adalah terletak pada kenyataan bahwa pada akhirnya UU itu akan diberlakukan ditengahtengah masyarakat. Padahal masyarakat itu adalah dinamis menuju perubahan sesuai dengan tingkat perkembangan kehidupannya. Oleh karena itu, dalam merumuskan suatu RUU perlu diketahui kondisi riil masyarakat dan proyeksi perkembangan masyarakat ke depan. Dengan demikian, suatu UU yang dihasilkan tidak akan jauh dari perkembangan dinamika masyarakat, dan pada gilirannya UU tersebut dapat dilaksanakan, ditegakkan dan berguna dalam menciptakan tatanan kehidupan masyarakat. Hal inilah, yang sering dikemukakan sebagai dasar sosiologis suatu pembentukan UU. Artinya, tanpa adanya dasar sosiologis, maka suatu UU hanya akan berupa lembaran-lembaran kertas mati yang tidak bermakna, karena tidak berlaku secara efektif di masyarakat. Di sinilah periunya orang atau kelompok yang akan merancang RUU melihat hukum dari sisi yang lain, tidak semata-mata hanya mengutamakan kepastian tetapi melupakan kemanfaatan.

\footnotetext{
52Journal Volume 9, Issue 2, Start Page 149-159 ISSN 13600834, Legislative Technique as Basis of a Legislative Drafting System Information \& Communications Technology Law, Abindon, Jun 2000.
} 
Kesulitan keempat dalam penyusunan RUU adalah terletak pada persoalan teknik perancangan. ${ }^{53}$ Masalah teknik perancangan ini bertalian dengan persoalan-persoalan teknis dalam penyusunan RUU. Artinya, bagaimana seseorang atau kelompok yang akan mengatur suatu objek kehidupan dalam sistematika dan format aturan hukum yang baku. Dengan kata lain, persoalan teknik perancangan ini merupakan tempat penuangan ide atau gagasan yang memuat dasar filosofis, yuridis dan sosiologis dalam suatu format dan bahasa hkum yang baku. Oleh karena itu, persoalan kesulitan teknik perancangan ini kadang-kadang dapat menggagalkan suatu penyusunan RUU. Jadi, ide atau gagasan yang baik untuk pengaturan suatu obyek kehidupan bersama dalam suatu masyarakat, dapat gagal dan terbengkelai karena ketidakmampuan perancang menguasai teknik perancangan peraturan perundang-undangan.

\section{Materi yang Diusung Partisipasi Masyarakat dalam Proses Pembentukan UU}

Pada dasarnya berbagai materi yang diusung dalam partisipasi masyarakat dapat diabstraksikan dalam HAM. Secara umum, subtansi materi yang diusung oleh pelakupelaku partisipasi masyarakat adalah menyangkut persoalan pengakuan dan perlindungan terhadap hak asasi manusia
(HAM). ${ }^{54}$ Pertama, persoalan HAM yang diusung dalam partisipasi masyarakat proses pembahasan RUU Sisdiknas adalah : HAM di bidang keagamaan yaitu, hak untuk memperoleh kebebasan dalam memilih agama. Kedua, berkaitan dengan RUU Pemilu adalah HAM di bidang politik yaitu, hak untuk memperoleh persamaan dan kebebasan politik. Ketiga, berkaitan dengan RUU Ketenagakerjaan adalah HAM di bidang sosial ekonomi, yaitu hak untuk mendapatkan penghidupan yang layak bagi kemanusiaan.

Secara lebih rinci hak dan tuntutan yang diperjuangkan oleh masyarakat adalah sbb: a. RUU Sisdiknas berkaitan dengan (i) persoalan agama dalam Pasal 12; (ii) persoalan dukungan dan desakan segera disahkannya RUU Sisdiknas; (iii) persoalan penundaan dan penolakan terhadap RUU Sisdiknas. b. RUU Pemilu bertalian dengan (i) persoalan pemisahan atau penggabungan pemilihan legislatif dengan pemilihan presiden; (ii) persoalan sistem pemilu; (iii) persoalan peserta pemilu; (iv) persoalan penanggung jawab dan penyelenggara pemilu; v) persoalan pelaksanaan pemilu; (vi) persoalan pengawasan pemilu; (vii) persọalan keterwakilan perempuan dalam parlemen; (viii) persoalan TNI/Polri dalam pēmilu; (ix) persoalan kampanye pejabat publik; $(x)$ persoalan daerah pemilihan : antara jumlah penduduk dan wilayah administratif; dan (xi) persoalan Golput dalam pemilu. Dari kesebelas

\footnotetext{
${ }^{53}$ Bagir Manan, Dasar-dasar Peraturan Perundang-undangan, Cetakan Pertama, Ind.-Hill. Co., Jakarta. him. 19.

${ }^{54}$ Berkaitan dengan HAM ini, Perubahan UUD 1945 mengatur 27 materi yang dapat dikelompokkan dalam lima (empat pen.) hal sbb.: i. kelompok hak-hak sipil; ii. kelompok hak-hak politik, ekonomi, sosial dan budaya; iil. kelompok hak-hak khusus dan hak atas pembangunan; dan iv. kelompok tanggungjawab negara dan kewajiban asasi manusia; Lihat Jimly Asshiddigie, Konstitusi, op. cit., hlm. 104- 109.
} 
materi yang diusung dalam partisipasi masyarakat untuk pembentukan UU Pemilu dapat dikelompokkan dalam empat hal yaitu : pertama, peserta pemilu; kedua, sistem pemilu; ketiga, penanggungjawab dan penyelenggara pemilu; dan keempat, pelaksanaan dan pengawasan pemilu. c. RUU Ketenagakerjaan bertalian dengan (i) persoalan kontrak kerja waktu tertentu (KKWT); (ii) persoalan pekerja lepas (outsourcing); (iii) persoalan cuti haid, menyusui dan tempat ibadah; (iv) persoalan pengupahan dan kesejahteraan; (V) persoalan hak mogok dan walk out; dan (V) persoalan penundaan dan penolakan RUU PPK.
Mencari model ideal partisipasi masyarakat dalam pembentukan UU di Indonesia

Untuk memperoleh gambaran dari model ideal partisipasi masyarakat dalam pembentukan UU di Indonesia, kiranya ada baiknya kita melihat pada "The Possible Ideal for South Africa" dalam proses pembentukan UU yang partisipatif di Afrika Selatan. Dalam gambaran model ideal yang dilakukan di Afrika Selatan ini, pada hakekatnya adalah bagaimana memberikan kesempatan kepada berbagai kekuatan yang terdapat dalam masyarakat terlibat dalam proses pembentukan UU. Sebab, esensi kekuasaan dalam suatu negara terletak dalam berbagai kekuatan yang dapat dilthat dalam ragaan sbb. :

Tabel 1.

The Possible Ideal for South Africa

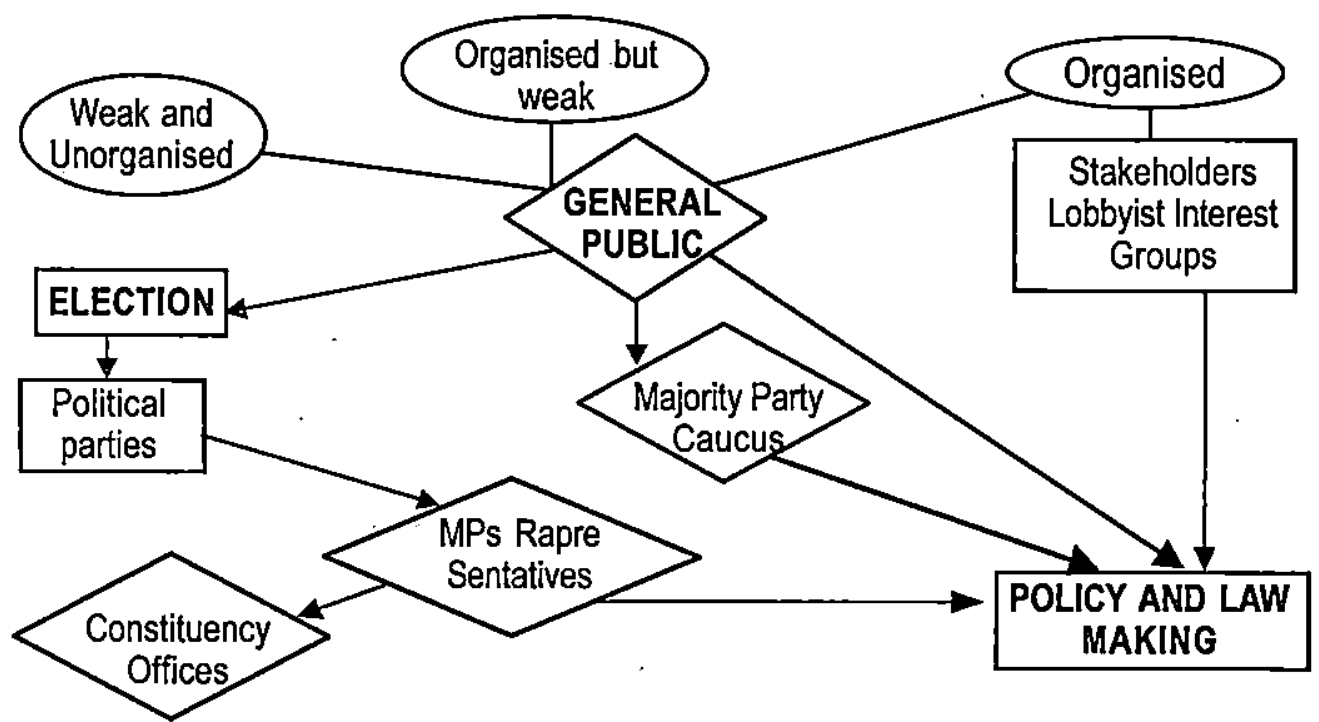

Sumber: A People's Government The People's Voice, Section 3 Public Participation in Theory and Practice : Loking at Alternative Models. 
Dari ragaan di atas, tampak bahwa idealita dari konsep tersebut terletak pada "kebersamaan" dari berbagai kekuatan publik yang secara nyata terdapat dalam masyarakat terlibat dalam proses pembentukan UU. Kekuatan-kekuatan publik ini mencakup: "These include citizens (through public participation), citizens (trough their representatives and constituency offices). Lobbyist and interest group, political parties represented in the legislature (trough comittes) and the majority party caucus (as a joint legislative-executive forum). ${ }^{n 55}$ Dengan demikian proses pembentukan UU yang partisipatif di Afrika Selatan tidak didominasi oleh satu kekuatan politik, tetapi menjadi milik semua kekuatan yang terdapat dalam masyarakat.

Setelah mempelajari "The Possible Ideal for South Africa" dalam proses pembentukan UU, maka pertanyaannya adalah bagaimana dengan Indonesia ? Apakah model partisipasi tersebut dapat pula diterapkan di Indonesia ? Apa faktor pendukung dan penghambatnya dalam proses pembentukan UU sebagaimana digambarkan di atas ?

Pertama-tama perlu dikemukakan bahwa antara Afrika Selatan dan Indonesia termasuk dalam Negara yang sedang memasuki masa transisi dari cengkeraman otoritarian menuju Negara demokrasi modern. Oleh karena itu kondisi sosial politiknya tidak jauh berbeda. Artinya, sama-sama terjadi proses pemberdayaan rakyat dalam berbagai aspek kehidupan bermasyarakat, berbangsa dan bernegara. Dengan demikian, melalui berbagai modifikasi sesuai dengan sistem ketatanegaraan yang dianut di Indonesia pasca perubahan UUD 1945, model partisipasi masyarakat dalam proses pembentukan UU di atas dapat diadopsi di Indonesia.

Pengadopsian ini didukung pula oleh kenyataan bahwa setelah reformasi 1998 proses pembentukan UU di Indonesia melibatkan berbagai pihak yang pada essensinya adalah kekuatan-kekuatan riil dalam masyarakat. Sebagaimana data yang ditemukan dalam penelitian ini56 menunjukkan adanya peran dari Pemerintah, DPR dan LSM, pakar \& pengamat, kelompok professional, Perguruan Tinggi, organisasi kemasyarakatan dsb. Pemerintah mewakili jajaran birokrasi yang pada akhirnya akan menjadi pelaksana bagi berlaku dan tegaknya UU dalam masyarakat. DPR mewakili rakyat melalui Pemilu dari berbagai Partai Politik yang secara riil memperoleh dukungan suara dari rakyat sesuai dengan electoral threshold yang telah ditentukan. LSM mewakili stakeholders yang dapat membangun kekuatan publik untuk melakukan pressure group melalui berbagai statement-statementnya yang pada gilirannya dapat pula melahirkan kekuatan unjuk rasa untuk menekan lembaga legislatif. Pakar \& pengamat serta kelompok professional dapat mewakili interest group yang secara langsung mempunyai kepentingan terhadap adanya suatu UU. Perguruan Tinggi yang dapat berperan menyumbangkan konsep-konsep pemikirannya sesuai dengan disiplin keilmuannya. Dan organisasi-organisasi

${ }^{55} \mathrm{http://www.parliament.gov.za/pls/portal30/docs/Folder} \mathrm{Parliamentary} \mathrm{-Information/Publications} \mathrm{Peoplel}$ chap16.html, loc. cit. Akses 23 September 2004 jam 18. 15.

${ }^{56}$ Lihat naskah utuh disertasi Bab IV Sub A tentang Penyajian Data dari tiga UU yang diambil contoh - sebagai penelitian yaitu RUU Sisdiknas, RUU Pemilu dan RUU Ketenagakerjaan. 
kemasyarakatan lainnya yang dapat berperan sesuai dengan kepentingannya masingmasing. Semua pelaku-pelaku partisipasi masyarakat tersebut dapat secara bersamasama berperan dalam proses pembentukan UU, karena adanya dukungan tatanan politik yang lebih terbuka, partisipatif dan akuntabel di Indonesia setelah memasuki Era Reformasi sejak tahun 1998. Jadi, di Indonesia terdapat faktor pendukung bagi terwujudya proses pembentukan UU yang partisipatif sebagaimana dipraktekkan di Afrika Selatan yaitu tatanan politik yang menuju proses demokrasi modern dan kesadaran masyarakat dalam bernegara.

Selain terdapat faktor pendukung, terdapat pula faktor penghambat dalam mewujudkan proses pembentukan UU yang partisipatif secara ideal di Indonesia. Meskipun dari tiga UU yang diteliti terdapat peran serta dari berbagai kekuatan politik dalam proses pembahasan RUUnya, tetapi keterlibatan partisipasi masyarakat masih belum seperti yang diinginkan. Artinya, partisipasi masyarakat masih sebatas pada didengar dalam RDPURDPU, dan belum memasuki wilayah pada rapat-rapat yang secara intens membahas materi RUU dalam Komisi/PANSUS maupun Panitia Kerja. Hal ini disebabkan pada tidak adanya perangkat peraturan yang memberikan peluang bagi masyarakat untuk dapat terlibat dan mengakses secara langsung perdebatan yang terjadi di Komisi/PANSUS maupun Panitia Kerja. Oleh karena itu, faktor penghambat ini perlu diatasi dengan membuat adanya UU yang mengatur partisipasi masyarakat dalam proses pembentukan UU. Agar DPR mendengar, memperhatikan dan bersedia untuk mengatur partisipasi masyarakat dalam proses pembentukan UU ini, maka harus diberikan landasan konstitutionalnya dalam UUD 1945 sehingga DPR terikat untuk membuatnya.

\section{Partisipasi Masyarakat Dalam UU No. 10 Tahun 2004}

Setelah enam puluh tahun merdeka dan lima tahun berjalannya reformasi, bangsa Indonesia baru memiliki undang-undang yang mengatur secara khusus tentang pembentukan peraturan perundang-undangan yang di dalamnya termasuk pembentukan UU. Padahal sejak awal lahirnya Negara Kesatuan Rl, the founding fathers telah meletakkan prinsip kedaulatan rakyat dan prinsip negara hukum harus berjalan bersama-sama dalam menata kehidupan bermasyarakat, berbangsa dan bernegara. Oleh karena itu, adanya UU No. 10 Tahun 2004 tentang "Pembentukan Peraturan Perundang-undangan" ini merupakan suatu qonditio sine quanon dan sebagai pijakan dasar dalam mewujudkan tertib hukum pembentukan peraturan perundangan dalam suatu Negara demokrasi di Indonesia. Dengan kata lain, melalui UU ini diharapkan akan terdapat adanya tertib pembentukan peraturan perundang-undangan sejak perencanaan sampai dengan pengundangannya. Hal ini karena dalam UU No. 10 Tahun 2004 ini diatur sistem, asas, tata cara penyiapan dan pembahasan, teknik penyusunan maupun pemberlakuannya. Jadi, adanya UU ini diharapkan akan terwujud suatu tatanan peraturan perundang-undangan yang baik. ${ }^{57}$

${ }^{57}$ Lihat Penjelasan Umum UU No. 10 Tahun 2004 dalam Jazim Hamidi, Pembentukan Peraturan Perundang-undangan Dalam Sorotan, (Cetakan Pertạma, Tata Nusa, Jakarta, 2005), hlm. 33. 
Dalam UU No. 10 Tahun 2004 tentang Pembentukan Peraturan Perundangundangan ini, secercah harapan pintu sempit partisipasi masyarakat diatur dalam Bab X yang hanya terdiri dari satu pasal, yaitu, Pasal $53 \mathrm{sbb}$ : "Masyarakat berhak memberikan masukan secara lisan atau tertulis dalam rangka penetapan maupun pembahasan rancangan undang-undang dan rancangan peraturan daerah. ${ }^{n 8}$ Sementara itu Penjelasan Pasal 53 menyatakan: "Hak masyarakat dalam ketentuan ini dilaksanakan sesuai dengan Peraturan Tata Tertib Dewan Perwakilan Rakyat/Dewan perwakilan Rakyat Daerah. ${ }^{59}$

Dari ketentuan Pasal 53 beserta Penjelasannya tersebut, tampak bahwa meskipun digunakan rumusan "berhak", ${ }^{60}$ yaitu "masyarakat berhak untuk memberikan masukan" tetapi tidak mengatur lebih lanjut tentang partisipasi masyarakat dalam proses pembentukan UU. ${ }^{61}$ Akan tetapi, dalam penjelasan pasal ini dikemukakan bahwa pelaksanaan hak masyarakat untuk memberikan masukan ini, diatur lebih lanjut dengan Peraturan Tata Tertib DPR/DPRD.

Dalam rangka menindak lanjuti ketentuan Pasal 53 beserta penjelasannya tersebut, dalam Pasal 139, Pasal 140 dan Pasal 141 Keputusan DPR No. 15/DPR RI///2004-2005 tentang Peraturan Tata Tertib DPR-RI diatur mengenai partisipasi masyarakat. Dari tiga pasal tersebut pada dasarnya hanya ada 3 materi yang berkaitan dengan partisipasi masyarakat yaitu : partisipasi masyarakat dalam penyiapan RUU; partisipasi masyarakat dalam pembahasan RUU; dan kegiatan alat kelengkapan yang menangani RUU untuk melakukan RDPU, seminar atau kegiatan sejenis, dan kunjungan.

Partisipasi masyarakat ini dapat dilakukan secara lisan maupun tertulis dalam rangka penenyiapan dan pembahasan RUU. Untuk penanganan lebih lanjut terhadap partisipasi masyarakat ini, alat kelengkapan yang menyiapkan atau membahas RUU dapat melakukan RDPU, seminar atau kegiatan sejenis, dan kunjungan. Selanjutnya, hasil pertemuan dan masukan yang diberikan secara tertulis menjadi bahan masukan terhadap RUU yang sedang dipersiapkan atau RUU yang sedang dibahas dengan Presiden.62

Dengan melihat pada kenyataan di atas, tampaknya partisipasi masyarakat belum dianggap sebagai sesuatu yang harus dipertimbangkan secara serius oleh DPR, mengingat tidak ada ketentuan yang mengatur tentang pengawasan dari masyarakat terhadap tindak lanjut dari masukan partisipasi yang telah diberikan. Pengaturan partisipasi masyarakat dalam Peraturan Tata Tertib DPR tersebut, baru sebatas prosedur pembahasan masukan. Memang terdapat bagian yang

\footnotetext{
${ }^{58}$ Jazim Hamidi, ... op. cit., hlm. 76 .

59lbid.

${ }^{\infty}$ Rancangan semula pasal yang mengatur tentang partisipasi ini, tidak menggunakan kata "berhak", tetapi digunakan kata "dapat". Dengan kata "dapat" berarti tidak ada kewajiban dari DPR untuk melakukan partisipasi masyarakat. Attinya, DPR mempunyai dua pilihan yaitu: boleh melakukan partisipasi publik atau boleh juga tidak melakukan partisipasi masyarakat. Lihat Emi Setyowati, Geliat Dari Ruang Sempit Partisipasi, Parlemen NetV-02C. htm.

${ }^{61}$ M Nur Solikhin, Partisipasi: Sebuah Harga Mati, www. Partemen Net, him. 2.

${ }^{6}$ /bid.
} 
menegaskan bahwa masukan-masúkan dari masyarakat yang telah melalui tahapan pembahasan dengan alat kelengkapan dijadikan bahan masukan dalam menyiapkan dan membahas RUU.63

Meskipun demikian, pengaturan partisipasi masyarakat dalam Peraturan Tata Tertib DPR ini, merupakan langkah maju bila dibandingkan dengan Peraturan Tata Tertib DPR sebelumnya. Hal ini karena dalam Peraturan Tata- Tertib DPR sebelumnya tidak diketemukan ketentuan yang mengatur partisipasi masyarakat dalam pembentukan UU. Akan tetapi, pengaturan partisipasi masyarakat dalam Peraturan Tata Tertib DPR ini akan lebih baik jika diberikan ruang pengawasan oleh masyarakat tentang perkembangan dari masukan yang diberikannya. Karena tidakjarang, setelah diadakan RDPU, pembahasan RUU yang masuk dalam Panitia Kerja dilaksanakan secara tertutup, sehingga kontrol publik tidak berjalan. Dengan kata lain, DPR harus menerapkan prinsip transparansi sehingga masyarakat dapat mengikuti perkembangan pembahasan masukan atau usulan yang telah disampaikannya. ${ }^{64}$

\section{Simpulan}

Dari uraian di atas dapat disimpulkan, pertama, proses pembentukan UU di era reformasi dapat dilihat dalam empat aspek, yaitu: aspek kelembagaan, aspek masyarakat, aspek pengaturan dan aspek pembahasan RUU yang secara keseluruhan telah mendorong adanya transparansi, partisipasi dan akuntabilitas sehingga menghasilkan produk UU -meskipun belum sepenuhnyatelah mendekati rasa keadilan dalam masyarakat.

Kedua, partisipasi masyarakat mewarnai dalam proses pembentukan tiga UU yang dijadikan obyek penelitian yaitu UU Sisdiknas, UU Pemilu dan UU Ketenagakerjaan. Adanya partisipasi masyarakat dalam mewarnai proses pembentukan ketiga RUU tersebut dapat dilihat dari aspek: (a) pelaku partisipasi masyarakat; (b) cara menyampaikan partisipasi masyarakat; (c) bentuk partisipasi masyarakat, (d) materi yang diusung dalam partisipasi masyarakat; dan (e) tindak lanjut terhadap masalah-masalah krusial -yang umumnya berkaitan dengan HAM - sehingga mendorong lahimya UU yang agak responsif. Dari tiga UU yang diteliti, tampak persoalan yang berkaitan dengan HAM merupakan persoalan krusial yang sangat diaspirasikan sehingga tidak mudah untuk perumusannya.

Ketiga, proses pembentukan UU di era reformasi yang melibatkan Pemerintah, DPR dan masyarakat, pada dasarnya adalah suatu bentuk ideal dalam proses pembentukan UU yang partisipatif guna melahirkan UU yang responsif. Semua kekuatan politik secara riil termasuk masyarakat- ada di dalamnya. Akan tetapi, karena belum ditopang oleh perangkat peraturan perundang-undangan yang mengatur partisipasi masyarakat secara memadai, maka bentuk yang ideal tersebut belum dapat menghasilkan produk UU yang sepenuhnya responsif bagi keinginan masyarakat luas.

63/bid., hlm. 3.

64 /bid. 


\section{Daftar Pustaka}

Bagir Manan, Dasar-dasar Peraturan Perundang-undangan, Cetakan Pertama, Ind.-Hill. Co., Jakarta. - Dasar-dasar Konstitusional Peraturan Perundang-undangan Nasional, disajikan dalam pendidikan singkat "Kajian Perundang-undangan" untuk para pengajar Fakultas Hukum se Sumatera, yang diselenggarakan oleh Fakultas Hukum Universitas Andalas, tanggal $11-18$ Oktober 1993.

David Easton, A Framework for Political Analysis, (Cetakan Kesepuluh, Printice Hall, Inc., englewood Cliffs, $\mathrm{N} \mathrm{J}$, United States of America, 1965).

David Held, Models of Democrcy, Second Edition, Polity Press, Tahun 1996.

Erni Setyowati, Geliat Dari Ruang Sempit Partisipasi, Parlemen Net-V-02C. htm.

Gabriel A Almond, Sosialisasi, Kebudayaan dan Partisipasi Politik, diedit oleh Mochtar Mas'oed dan Collin Mc Andrews dalam Perbandingan Sistem Politik, (Gajah Mada University Press, Cetakan Keenambelas, Yogyakarta, 2001).

Gary Craig and Marjorie Mayo (Editor), Community Empowerment A Reader in Participation and Development, ( Zed Books Ltd., London \& New Jersy, 1995 Geoffrey de Q. Walker, Initiative and Referendum : The People's Law, (The Centre for Independent Studies, Australia, 1987).

Hari Chan, Modern Jurisprudence, International Law Book Services, Kuala Lumpur, 1994.

Jazim Hamidi, Pembentukan Peraturan

Perundang-undangan Dalam Sorotan, (Cetakan Pertama, Tata Nusa, Jakarta, 2005).
Joeniarto Selayang Pandang Sumber-sumber Hukum Tata Negara di Indonesia, Liberty, Cetakan Keempat, Yogyakarta, 1983

Jimly Asshiddiqie : Gagasan Kedaulatan Rakyat Dalam Konstitusi dan Pelaksanaannya di Indonesia, (lkhtiar Baru Van Hoeve, Cetakan Pertama, Jakarta, 1994

,"Masukan Pakar yang Khusus Diundang Dalam Penyusunan RUU Pemilu", Risalah Sekretariat Pansus Pemilu 3 September 2002. Konsolidasi Naskah UUD 1945 Setelah Perubahan Keempat, Yarsif Watampone, (Cetakan Kedua, Jakarta, 2003).

, Konstitusi dan Konstitusionalisme Indonesia, Cetakan Kedua, (Sekretariat Jenderal dan Kepaniteraan Mahkamah Konstitusi, Jakarta, 2006).

Jufrina Rizal, Sosiologi Perundang-undangan, makalah yang disajikan dalam Pendidikan dan Latihan Tenaga Tehnis Perundang-undangan Sekretariat Jenderal DPR Rl, Jakarta, 1998/1999.

Loekman Soetrisno, Menuju Masyarakat Partisipatif, Cetakan ke 6, Kanisius, Yogyakarta, 1995

Moh Kusnardi dan Bintan R Saragih, Ilmu Negara, Cetakan Ketiga, Gaya Media Pratama, Jakarta, 1995.

Moh. Mahfud MD, Perkembangan Politik Hukum : Studi tentang Pengaruh Konfigurasi Politik Terhadap Produk Hukum di Indonesia, disertasi, UGM, 1993 M Nur Solikhin, Partisipasi : Sebuah Harga Mati, uww. Parlemen Net.

M. Tahir Azhary : Negara Hukum : Suatu Studi tentang Prinsip-prinsipnya Dilihat dari 
Segi Hukum Islam, Implementasinya pada Periode Negara Madinah dan Masa Kini, Bulan Bintang, Cetakan. Pertama, Jakarta, 1992.

Muh. Busyro Muqoddas dkk. (Penyunting), Politik Pembangunan Hukum Nasional, (UII Press, Yogyakarta, 1992).

Robert A Dahl, Democracy, Yale University Press, USA, 1998.

Perihal Demokrasi : Menjelajahi Teori dan Praktek Secara Singkat, Penerjemah A Rachman Zainuddin, Edisi Pertama, Yayasan Obor Indonesia, Jakarta, 2001.

Samuel P Huntington dan Joan Nelson, No Easy Choice Political Participation in Developing Countries, (Harvard University Press, USA, 1976).

Satjipto Rahardjo, IImu Hukum, Cetakan

Pertama, Alumni, Bandung, 1986.

Sekretariat Jenderal DPR RI, Lampiran

Laporan Sekretariat Jenderal DPR RI

Persidangan IV Tahun 1997/1998,
Jakarta, $1997 / 1998$. - Lampiran Laporan Sekretariat Jenderal DPR RI Tahun Sidang 1999/ 2000, Jakarta, 1999/2000. - Proses Pembahasan RUU Tentang Sistem Pendidikan Nasional, Jakarta, 2003.

Terence Ingman, The English Legal Process, Blackstone Press Limited, London, 1983.

Keputusan DPR RI No. 03A03A/DPR RI/II 2001-2002 tentang Peraturan Tata Tertib DPR RI.

Journal Volume 9, Issue 2, Start Page 149-159 ISSN 13600834, Legislative Technique as Basis of a Legislative Drafting System Information \& Communications Technology Law, Abindon, Jun 2000.

http://www.parliament.gov.za/pls/portal30l docs/Folder Parliamentary-Information /Publications People/chap16.html, Akses 23 September 2004. 